\title{
THE RELATIONSHIP BETWEEN EFQM LEVELS OF EXCELLENCE AND CSR DEVELOPMENT
}

\begin{abstract}
Purpose: This paper aims to analyse the level of CSR development, in accordance with the dimensions of Maon et al.'s (2010) model, that could be achieved when organisations adopt the EFQM model, as well as how the EFQM model can foster this CSR development.

Methodology: The research method chosen was a qualitative methodology involving multiple case studies. Our empirical research relies on an in-depth study of four cases of organisations recognised by the EFQM model in Spain.

Findings: Our findings show that, although a higher commitment to the EFQM model implies a greater level of CSR development, with the Knowledge and Attitudinal dimensions more developed thanothers, organisations still have to make CSR an internalised management ideology. Research limitations: The very nature of the process of EFQM assessment, which does not ensure uniformity in all aspects of management. Limitations that are inherent to cases studies: factors that can be chosen by the researcher, such as geographical location, size, sector and ownership, can have an influence on the characteristics of the CSR practices that are found.

Practical implications: This study contributes to the literature on excellence by approaching the EFQM model as a tool to integrate CSR issues into management.

Value: To the best of our knowledge, no previous analysis has been performed to address the potential relationship between CSR development in accordance with Maon et al.'s (2010) model and commitment to excellence.
\end{abstract}

KEYWORDS: EFQM, Excellence, CSR, Maturity, Assessment. 


\section{INTRODUCTION}

Although there is no single approach that incorporates Quality Management (QM) and CSR, there are several frameworks that have combined both (Waddock and Bodwell, 2004). Among these frameworks, the EFQM Excellence Model, which is one of the most used Business Excellence Model across European organisations (Araújo and Paulo, 2014), provides best practices to take into account the impact that organisational activity has on society and to balance the needs of different stakeholders (McAdam and Leonard, 2003; Asif et al. 2011). Moreover, Jasiulewicz-Kaczmarek (2014) find that the literature acknowledges that the approaches based on business excellence models, such as the EFQM Model, are used by organisations for the integration of CSR into business processes. In this regards, representative papers may be Tokarcikova et al., (2014), who considered the EFQM model to be one of the most commonly used methods for evaluating CSR; Olaru et al. (2011) that show how specific values of CSR are comprised into the EFQM Excellence Model; or Avlonas y Swanninck (2009), who exhibit how organisations adopting the EFQM model are more likely to increase value for stakeholders that those not adopting the model. Even the EFQM launched various initiatives related to CSR, such as the recently published EFQM Framework for Sustainability (EFQM, 2015).

While previous research has noted a relationship between the EFQM model and CSR, no study has been conducted to determine how organisations develop CSR practices by adopting the EFQM model, or how far they can go in this development. Some studies in the broader QM literature (e.g. Mohammad et al., 2011) concluded that high commitment to excellence would entail an integrated adoption of practices, while organisations that reach a lower commitment to excellence are likely to exhibit a more piecemeal adoption. Hence, one may expect differences in the development of CSR practices depending on the commitment to excellence, since this is a transversal topic in the EFQM model, which may only be developed when an integrated adoption 
takes place.

In this context, the purpose of this study is to analyse the level of CSR development, in accordance with the dimensions of Maon et al.'s (2010) model, that could be achieved when organisations adopt the EFQM model, as well as how the EFQM model can foster this CSR development. In doing so, this paper contributes to the scientific assessment of the EFQM model by providing an analysis of how commitment to excellence can lead to an advanced CSR development, and could make it clear what kind of actions organisations need to develop in order to improve their CSR development. Accordingly, it sheds light on how much value can be produced by the adoption of the EFQM Excellence Model.

To reach our purpose, this paper is structured as follow. In section 2 we outline the theoretical relationships that exist between the model of Maon et al. (2010) and the adoption of the EFQM Excellence Model. We will then go on to describe the research methodology used and to present the results of an empirical study aimed to explore the research formulated question. Lastly, the findings from the study, its limitations and future lines of research are all discussed.

\section{ADOPTION OF THE EFQM EXCELLENCE MODEL AND CONSOLIDATIVE CSR DEVELOPMENT}

\subsection{LEVELS OF EXCELLENCE ACCORDING TO THE EFQM MODEL}

The EFQM Excellence Model offers a global vision of management that is oriented towards accomplishing balanced results for all the stakeholders (Bou et al., 2009; EFQM, 2012). Figure 1 depicts the current EFQM Excellence Model as well as their criteria weights. This structure promotes an assessment of what an organisation does and the identification of what is actually achieved, thus enabling an evaluation of the progress an organisation is making towards excellence (Jayamaha et al., 2009). 
Figure 1

The EFQM launched a scheme of recognition to acknowledge firms that obtain a certain score using the EFQM Model (1000 points being the maximum score). This score is achieved after carrying out a thorough process of self-assessment followed by an external assessment in which the performance of the organisations is reviewed in each of the EFQM Model criteria using the results-approach-deployment-assessment and refinement (RADAR) assessment (EFQM, 2012). According to this recognition scheme, firms can be accredited at 4 levels: Committed to Excellence 200+; Recognised for Excellence 300+; Recognised for Excellence 400+; Recognised for Excellence 500+ (if more than 200, 300, 400 and 500 points are obtained, respectively). This scheme of recognition fits the definition of Maturity Models given by Van Aken et al. (2005), who describe them as the ones that demand the assessment of the performance of key systems of the entire organisation in order to create a high-performance company. At the same time presents the idea of adopting the EFQM Model as an evolutionary process in quite a clear way (Dale and Lascelles, 1997).

\subsection{CONSOLIDATIVE CSR DEVELOPMENT BASED ON THE EFQM EXCELLENCE MODEL}

The Consolidative Model of CSR Development of Maon et al. (2010), represented in Table 1, serves as a guide for organisations convinced of the need to integrate CSR within their management. It's more important contribution is that the model considers the path towards CSR as moving through three cultural phases - CSR reluctance, CSR grasp and CSR embedmentwhich range from an absolute rejection of it to an attitude of full integration with the organisation's other policies and programmes. 
Table 1

In a more detailed form, the authors consider CSR development as taking place in seven stages, each of which is characterised by a different level of integration of CSR within management and by a different level of development of distinct organisational characteristics grouped within the three Dimensions proposed by the researchers: Knowledge and attitudinal dimension, Strategic dimension, and Tactical and operational dimension.

Taking the model of Maon et al. (2010) as our starting point, we will analyse the level of maturity in CSR, that is, the stage of CSR development that the adoption of the EFQM Model is able to attain. To achieve this aim, the analysis is based on the stage of CSR development that different levels of commitment to the EFQM model are capable of developing, as well as how the EFQM model can foster CSR development.

\subsubsection{CAPABILITY-SEEKING STAGE AND COMMITTED TO EXCELLENCE}

The use of the EFQM Model as a referent in management together with the experience of the organisation in the process of attaining the Commitment to Excellence 200+, which involves a process of self-assessment and the establishment of improvement plans, generates some organisational processes and values that reflect special attention towards stakeholders, which may place an organisation at stage four "capability-seeking" of the model of Maon et al. (2010) (see Table 1). In accordance with this model, although there is an instrumental stakeholder culture, this stage can be considered the beginning of clear CSR management: the relationships with stakeholders are more interactive, there is an increased awareness of issues related to CSR and the reputational risks associated with leaving these questions aside. Authors such as Castka et al. 
(2004a) had also taken the standard ISO 9001, which can be compared to a Committed to Excellence $200+{ }^{1}$, as the beginning of the path towards gaining an understanding of CSR.

Regarding the specific dimensions of the model of Maon et al. (2010), the Support of top management to go on to stage four of CSR can be achieved with a level of excellence 200+ since the leadership and commitment of top management is fundamental and must be present in an organisation on using the EFQM Model (Pedersen and Neergaard, 2008). This involvement of top management has repercussions on the Stakeholders' relationship. The interactivity required by Maon et al. (2010) can be fostered by adopting the EFQM model, since using it as a management framework makes it possible to satisfy the needs of the different stakeholders in a balanced manner (McAdam and Leonard, 2003; Isaksson, 2006; Tarí, 2011). An organisation that has adopted the model and obtained at least a Committed to Excellence 200+ will be managing itself according to the Fundamental Concepts of Excellence, which include the need to orientate oneself towards stakeholders such as customers, employees, suppliers, partners or the community in general as a way to achieve sustainable excellence.

With regard to Transparency and reporting, the self-assessment process, which organisations have to undergo to attain the recognition, bestows upon an organisation an attitude of information and transparency or, in other words, accountability. As claimed by Alfaro et al. (2011, p. 855), the information provided from self-assessment "can be used to describe a large number of a priori hidden factors that favour the understanding of the whole organisation". This attitude allows organisations to be inclined towards the submission of reports, which would place them in at least stage four of the model of Maon et al. (2010), a stage in which there is a turning point between a

\footnotetext{
${ }^{1}$ In the recognition scheme, the standard ISO 9001 is related with the first level of excellence: Commitment to Excellence 200+. Although having previously implemented the standard ISO 9001 is not a necessary condition, many organisations do start out from there in the search for higher levels of performance after having reached an impasse that does not allow them to continue with the spiral of learning and improvement or on a search for differentiation (Marimon et al. 2009).
} 
posture of justification and a posture of information. Moreover, as claimed by Jacobs and Suckling (2007), excellence models provide a basis for evaluating the progress that has been made towards previously established goals. In this sense the creation and implementation of improvement plans, which are derived from the self-assessment needed to obtain the Committed to Excellence 200+, make it possible to develop a series of organisational routines and practices that foster the establishing of Performance objectives and the Structuring of initiatives in the form of action plans that answer to and anticipate the stakeholders' expectations, which characterise an organisation located at stage four of CSR development.

\subsubsection{MAON ET AL.'S MORE ADVANCED STAGES AND HIGHER LEVELS OF EXCELLENCE}

From this fourth stage onwards, reaching higher commitment to excellence may lead to progressive leaps in the stages proposed by Maon et al. (2010), thus dragging the development of the management towards greater CSR commitments. This can be explained if we consider the assessment processes that organisations follow to increase the level of excellence, which allow knowledge to appear in the form of strengths, areas of improvement and action plans (Van der Wiele et al., 2000; Balbastre et al., 2005). Some researchers, such as Balbastre (2006) or CalvoMora et al. (2015), found that self-assessment against the EFQM model may foster a learning process thanks to both the establishment of a common knowledge through the use of the same reference model, and the continuous provision of information regarding processes and the use of methods to improve them. The assessment processes needed to achieve the EFQM Recognition imply (e.g. Balbastre et al., 2005; Tarí, 2010) management commitment, the development of improvement plans and follow-up and the establishment of an organisational climate that supports the values and elements inherent to the process. Thus, an organisation that has completed successive self-assessment cycles in order to reach higher commitment to excellence 
would be an organisation in which knowledge has been generated and certain competencies related with management's commitment or the setting of objectives and planning of actions have been developed.

If we examine the characteristics of the different stages of the model of Maon et al. (2010), we find that the commitment of management, the structuring of initiatives and the setting of objectives are the basic aspects that must be developed in order to advance in the commitment to CSR. Another basic element is the drafting of reports and transparency, which can also be carried out within the processes of self-assessment, since an organisation that aims to achieve any Recognised for Excellence is required to draft a Conceptual Report (CEG, 2014) in which the organisation must detail the good management practices it employs and their link with the results. This exercise in transparency, typically just internal, will be reinforced if the organisation undertakes the practice of allowing access to this document to more stakeholders, for example, by posting it on its website.

In short, the dynamic process of self-assessment which has to be undertaken in order to reach higher levels of excellence can generate a process of learning and an organisational context that are conducive to higher levels of commitment to CSR. These expectations motivate our research question: what level of Corporate Social Responsibility (CSR) development, following Maon et al.'s (2010) model, can be achieved by using the EFQM Model as a management model and how can the EFQM model foster CSR development?

\section{RESEARCH METHODS}

The research method chosen was a qualitative methodology involving multiple case studies. This methodology is considered appropriate since a direct access to the organisations is needed in other to know the actual practices used in a real-life context. In selecting the sample, an explicit 
methodological design was chosen which embrace all the most relevant proposals from the academic literature, such as Eisenhardt (1989) or Yin (1998). As part of this design, validity, reliability and consistency were taken into account in order to ensure the scientific quality of the study, following Yin (1994, 1998) and Maxwell (1996).

\subsection{SAMPLE}

The case studies were chosen by searching for those which allowed a greater opportunity for learning. To prevent business sector to cause a distortion in the study, authors decided to apply the principle of homogeneity (Patton, 1990). Hence, organisations from the same business area were chosen. The geographical area chosen was the Principality of Asturias in Spain, where an important increase in the number of organisations with recognitions has taken place (CEG, 2011). One organisation per level of Recognition was chosen: Autoridad Portuaria de Gijón (APG, Port Authority of the city of Gijón) (500+), INMER (400+), CTAI Ingeniería (300+) and Asturfeito $(200+)$. Table 2 shows the most relevant data for each of the cases analysed. The research was carried out between May and November 2012.

Table 2

\subsection{INSTRUMENTS USED IN THE CASE STUDY}

The research was based on a number of different sources, using triangulation to ensure that the study is reliable and valid (Eisenhardt, 1989). The actual process of granting recognitions has its own system of triangulation, as there are three sources of information: self-assessment; validation of self-assessment carried out by external experts, and the assessment by an external team. This process gives methodological robustness to the recognitions scheme.

First, face-to-face interviews were used to collect evidence. In order to ensure the reliability of the information, the method followed by Done et al., (2011) was chosen, and therefore at least 
three people were interviewed separately in each case: the highest executive in the organisation; the person/s responsible for implementing CSR practices; and a group of employees that could vary in number (depending on the size of the workforce and the complexity of the organisational chart), which would provide the researcher with evidence confirming the implementation of CSR-related practices. The interviewees were asked to self-assess the degree of CSR development in the organisation on one of the seven levels for each of the dimensions of CSR defined by Maon et al. (2010) (see Table 1). To avoid social desirability, the columns that define the CSR Cultural phase, the CSR Development stage and the CSR Vision and pre-eminence of the organisational culture were withdrawn from the summary chart of the model of Maon et al. (2010).

Second, a conversation based on the interviewee's responses was proposed with the purpose of providing (and indeed produced) verifiable evidences, such as allocated resources, KPIs or an adequate planning, to back up his or her statements so as to allow the researchers, in the light of the examinations of the documents presented, to carry out the corresponding triangulation.

Third, as standards have been used in the academic literature as a system for measuring CSR, organisations were also asked if they had implemented any norms and standards considered to be proxies of CSR, following Gjølberg (2009), Taneja et al., (2011) or Maas and Reniers (2013). Examples of such norms and standards include: membership of CSR communities (i.e. UN Global Compact); sustainability information practices (i.e. KPMG Sustainability Reporting Survey and Global Reporting Initiative); and certification schemes (i.e. ISO 9001, ISO 14001, EMAS Regulation, OHSAS 18001, ISO 27001, UNE 166002). In this regard, we reviewed all the documents related with the implemented managements systems, whether certified or not.

Fourth, the documents from the whole cycle of the self-assessment and assessment process against the EFQM Model were reviewed. In the case of Asturfeito this involved 1 cycle (2010), 4 
cycles for CTAI Ingenería (from 2004 to 2010), 3 cycles in the case of INMER (from 2007 to 2011) and 4 cycles for APG (from 2002 to 2010). It is worth noting that organisations may have not sought an external recognition, although they may apply processes to integrate CSR into management. Hence, some questions were also asked about the use of particular practices, following Agudo et al. (2012).

Further, the Guidance on self-declaration NEN NPR 9026:2011² (NEN, 2011) was also used. This publication has 40 guiding questions about adherence to ISO 26000. The relevance of using this document is based on the fact that by doing so “... organisations go through a series of procedures that encourage them to collect information, present evidence, build an argument in favour of their application of ISO 26000" (Moratis, 2015). The NPR 9026 was used by the researcher as a guide to inform the direct observation process, involving regular on-site visits by the researcher (at least four whole man-day visits), whose role is similar to that of the EFQM assessor.

The persons interviewed in each organisation, as well as the documents revised are show in Table 2.

\section{RESULTS}

In this section we present, for each organisation, the findings regarding the main elements in the model of Maon et al. (2010) that were developed as a consequence of adopting the EFQM model and the assessment associated to the process of achieving an EFQM recognition. In Tables 3, 4 and 5 organisations are located (using colours) in the stage of CSR development they have reached for each of the three groups of dimensions of Maon et al.'s model (2010). In these tables,

\footnotetext{
${ }^{2}$ More information can be found at NEN (2011). NEN White paper 'ISO 26000 Statement of application. https://www.nen.nl/web/file?uuid=a08e8b10-d65e-4b96-ae9e-a287b235dc1b\&owner=ccdd2a27-7f28-43b1-a3cbd01e2bf2a56a\&contentid=150021
} 
examples of the specific actions undertaken by the organisations are highlighted. The people interviewed agree in their answers, with just some different levels of intensity depending on the hierarchical level: managers consider that their organisations are more focused on CSR than is perceived by employees.

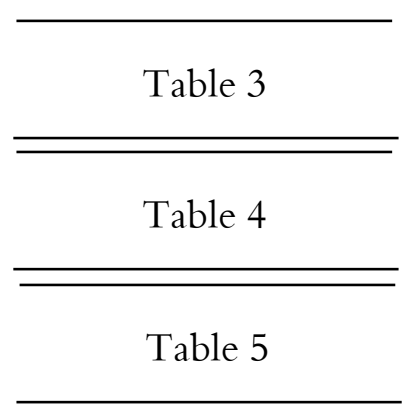

\section{Analysis of the four cases}

Asturfeito demonstrates its awareness of CSR with the presence of voluntary initiative issues such as certified management systems in environment and health \& safety (ISO 14001, OHSAS 18001). These standards allow Asturfeito to reach the "Caring Stage" in CSR development in certain elements of CSR (Support of top management or Resources commitment) and the "Strategising stage" in the element regarding Structuring of CSR initiatives. Moreover, since Asturfeito is UN Global Compact participant and has made a Sustainability Report in accordance with GRI, this organisation seems to exhibit a proactive orientation and initiates reporting efforts. However, due to the lack of public access to the reports, their Transparency and reporting dimensions is placed in an Internal reporting/Selective disclosure posture. Hence the level of Asturfeito's vision of CSR and prominence in organisational culture stands halfway between CSR as influential and CSR as embodied, mainly due to its membership of CSR communities, certification schemes and reporting efforts.

Asturfeito acknowledges that although clients do not consider the presence of certified management systems (i.e. ISO 9001, ISO 14001 or OHSAS 18001) as a sufficient guarantee, its 
CEO admits that these standards do allow organisations to improve processes and offer proof, up to a certain point, that all the organisation's process are running smoothly. At the same time these norms provide a certain kind of differentiation from competitors, at least in the early stages of commercial relations, which is coherent with the findings of Heras et al. (2006) and Marimon et al. (2009) regarding the search for differentiation, since the value of a certification is inversely proportional to the number of them on the market. The reason given by Asturfeito's CEO to explain why his organisation is involved in CSR activities such as Sustainability Reports and UN Global Compact is to allow employees to take actions in business initiatives which provide the organisation with value from both the external and the internal perspectives.

In the case of CTAI Ingeniería, since the organisation still adopts a quality focused stance, where views of CSR take an external requirements perspective, meeting all the legal requirements and the very exacting demands of its customers, we can place it within the "Compliance-seeking" stage. Its approach is focused on the hard dimensions of quality, which does not help in its efforts to reach higher stages in CSR development. However, it is worth noting that organisational climate surveys have been implemented since 2004 due to an area of improvement detected during an EFQM assessment cycle. The findings from this case suggest that this organisation finds itself in the assumption highlighted by Castka et al. (2004b), Vives (2006) or Sweeney (2007) where, given the limited resources of SMEs their approach to CSR is more theoretical than real, despite their genuine desire to implement it. It is reasonable to expect that in the near future CTAI Ingeniería will reach higher levels of CSR development due to the fact that the CSR orientation stated by its CEO is only lacking certain specific actions to support it. One of the reasons which was found to explain this inconsistency is the low impact of the organisations in the more widely acknowledged CSR dimensions, such as environment and social issues. We suggest that one of the motives underlying this is that organisations with fewer than 
100 employees are less inclined to be very involved in CSR actions because, depending on the size of an organisation (Graafland, 2002), cost can be a key factor for their survival (Ahmed et al., 1998). So, consequently, its vision of CSR and prominence in organisational culture is on the 'CSR as worthy of interest' level.

The level of INMER can be placed, like Asturfeito, halfway between CSR as influential and CSR as embodied, but closer to the first than Asturfeito. The reason for this is that, despite having certain dimensions of CSR with the same development as Asturfeito (see Tables 3, 4 and 5), the initiatives that were deployed cover sections of the CSR that are mainly related with quality topics. This means that INMER, through consecutive cycles of assessment, has deepened its knowledge of the quality management dimensions related with CSR and thus displayed an instrumental stakeholder culture more than a proactive approach. In this respect INMER would be an example of the CSR development path that organisations that are too focused on quality management could achieve.

APG presents a level of development where Knowledge and attitudinal dimensions in the model of Maon et al. (2010) are more advanced than the Strategic and Tactical and operational dimensions. Since APG, like Asturfeito, applies international standards like ISO 14001 and OHSAS 18001 or other initiatives such as UNE 166002, it is logical to think that the Tactical and operational dimensions would be at an advanced stage of development. The explanation for this finding may lie in the low degree of consideration granted by the interviewees to the section called Resources commitment. With regard to the other two dimensions, APG presents an important level of development that is sustained in initiatives like the Port Community Association $^{3}$ and the organisation of management according to the dimensions of CSR, which

\footnotetext{
${ }^{3}$ The Port Community Association is a mechanism to promote teamwork among the 92 organisations which are part of the Port Community. It consists of three forums, each of them focusing on a specific field (quality, safety and
} 
allows for a higher degree of definition in the actions performed in CSR. As a result, in terms of the stage of CSR development, APG is between CSR as embodied and CSR as influential.

\section{Knowledge derived from the four cases}

CTAI Ingeniería and INMER have a greater degree of development in the Knowledge and Attitudinal dimensions than in the Strategic and the Tactical and Operational dimensions. In the case of Asturfeito, the greatest degree of development is reached in the Tactical and Operational dimensions, followed by the Knowledge and Attitudinal dimensions, the Strategic dimensions being the least developed. For all four cases it can be said that a more robust development of the Knowledge and Attitudinal dimensions may mean that a change in attitudes is more attainable for organisations than a change in their way of doing things.

In a similar line, in the four cases ethics was evidenced as an important issue derived from the use of the EFQM model. Ethics is a pillar of CSR since it implies a more humane, more ethical and more transparent way of doing business (van Marrewijk, 2003). It is behind some of the elements of the model of Maon et al. (2010), particularly those in the Knowledge and Attitudinal dimensions. Indeed, during the conversations with the representatives of the four organisations, one of the issues that arose was ethics, in particular, building trust with clients. In the case of APG they also seek to generate this commitment with society at large too. This trust is constructed upon the proven capability of being able to meet the commitments the company has acquired, which can be identified with the concept of integrity, as defined by Erhard et al. (2009). In this regard, CTAI Ingeniería's CEO considers ethics as one of the organisation's more valuable assets. Sustaining commercial relationships with clients for more than 30 years would have been impossible without ethics. He also considers that ethics allows a group of people to

security, or promotion) under the coordination of the Association. More information can be found at: https://www.puertogijon.es/index.asp?MP=2\&MS=281\&MN=2 
work in a fairly independent way, spending a lot of time in clients' facilities and working with little or no support from head office, and to be able to form a homogeneous workforce with little staff turnover. In the same way as in the case of APG, the concept of integrity held by CTAI Ingeniería's CEO matches the one expressed by Erhard et al. (2009). In this particular case, integrity towards clients and employees is considered a key element with which to build the success of the organisation. In the case of APG, the Deputy Technical Director's view is that CSR is an issue that APG has to exercise as a reference within its sphere of influence. In this regard, the APG mentioned its leadership in the Port Community Association in areas such as Quality, Environmental issues and Health \& Safety.

To sum up, it appears that it is possible to distinguish a greater commitment to CSR as the commitment to excellence becomes higher. CSR is widely tackled through the use of quality practices oriented to processes management based on ISO or other standards or agreements. However, an almost total lack of strategic orientation regarding the integration of CSR into management is observed. Hence, it could be said that the adoption of certain standards is more "a license to operate" than a robust and harmonious process of alignment of management towards the development of CSR within the organisational structures and operations.

\section{DISCUSSION AND CONCLUSIONS}

\subsection{CONTRIBUTIONS IN THE ACADEMIC AREA}

Firstly, the main conclusion that can be drawn is that a relationship between the commitment to excellence and CSR development does exist. Our findings provide empirical evidence to support the claims by Tarí (2011) that QM and CSR have common philosophical roots, which display a significant amount of overlapping and several similar practices. This study shows that the iterated

process of successive assessment, both internal and external, has highlighted areas of 
improvement related with CSR. In line with the findings of Van der Wiele et al. (1996), Samuelsson and Nilsson (2002) and Ahmed et al. (2003), we conclude that a positive relationship can be established between the use of the assessment process against the EFQM model and the performance of organisations (in this study, in the specific case of CSR).

Yet, secondly, there is no uniformity in the development of CSR among the organisations studied. One of the possible reasons derives from the multiples approaches in adopting EFQM since organisations can achieve high commitment to excellence by shining in some criteria, although at the same time they rate poorly on others. That is, the final score (the basis upon which a recognition is granted) may not reflect a homogeneous level of performance in the EFQM Excellence Model. Despite CSR being a transversal topic that affects all the EFQM criteria, the resources allocated by organisations to CSR are not uniform and, in consequence, cannot be accompanied by high performance in each and every one of the dimensions of CSR.

Thirdly, the findings of the empirical study reveal the presence of different levels of CSR development for different dimensions of the model of Maon et al. (2010) among the four organisations studied. The adoption of the EFQM model seems to develop those elements of CSR concerning the use of systems to structure CSR initiatives, and the perception of CSR as an important issue. The systematisation of processes implicit in the EFQM model and in QM in general (e.g. Bou et al., 2009) may be responsible for this finding. However, a high level of excellence does not seem to promote progress in reporting or in the establishment of active management of CSR related initiatives such as Performance objectives and Coordination of CSR issues. It seems that these elements are not fully considered into the EFQM model and organisations may need some other frameworks to develop them. This finding tallies with Kok et al.'s (2001) opinion that the EFQM model does not drive a proactive position regarding CSR, while suggesting the additional use of an audit tool to assess CSR. 
Lastly, the actions observed in the organisations analysed reveal the inherently multidimensional nature of CSR (Waddock and Graves, 1997; Schreck, 2011). CSR practices are prioritised according to the impacts the organisation has, which is a good example of Argandoña and von Weltzein (2009) findings that CSR is a reflection on the nature of the firm role in society and its relationships with its internal and external stakeholders. For instance, organisations like Asturfeito and APG, with a greater environmental and occupational health impacts prioritise CSR practices concerning standards ISO 14001 and OHSAS 18001. In short, each organisation has to seek its own level of CSR development, depending on its organisational values (van Marrewijk and Werre, 2003), which means applying a contingency approach to CSR (Carroll, 1979; Rowley and Berman, 2000). Hence, an organisation does not necessarily have to go through all the stages of CSR development or even begin with the least advanced. This approach may change as a consequence of the appearance of certain situations (van Marrewijk, 2003) and the influence of the contextual characteristics of each organisation (Blombäck and Wigren, 2009).

As a concluding remark, it can be stated that the EFQM Model presents a solid, but limited, value proposition in CSR in the topics it addresses. This assertion is based on the fact that, given the clear processes orientation of the EFQM Model, it is relatively easy to implement certifiable standards, such as ISO 9001, ISO 14001 and OHSAS 18001, which have important synergies with different dimensions of CSR. However, organisations that adopt a management system in accordance with the EFQM Model of Excellence, and that do not have management systems in place concerning these norms or similar, can present lower levels of CSR development. This idea seems to tally with Waddock and Bodwell's (2002) work, in that most of the norms and frameworks focus on the management of social responsibility in a vertical way and, therefore, as they lack the ability to manage other areas of organisations that influence CSR, they cannot 
provide answers to the needs arising from the integration of CSR actions within the management system of organisations.

\subsection{MANAGEMENT IMPLICATIONS}

The results of the study allow us to suggest that CSR development could be achieved by way of the EFQM model, in particular the knowledge derived from the assessment process in the form of areas of improvement. Throughout the study it has been seen how organisations make use of certified management systems, such as ISO 9001, ISO 14001 and OHSAS 18001. Organisations that have reached high levels of excellence therefore seem to have sought (see Tables 3, 4 and 5) the operational support of these standards, which allow them to attain certain levels of development within certain dimensions of the evolutionary model of CSR. In contrast, in other dimensions of the model of Maon et al. (2010) these tools do not provide all the support required for a good integration of CSR within management. We are referring, in particular, to organisational elements like "Organisational sensitivity towards CSR issues", "Performance objectives" (when they do not refer to objectives related with the management systems that have been implemented), "Transparency and reporting" and "Coordination of CSR issues". The reason suggested explaining the existence of these shortcomings is that CSR actions have been undertaken in an uncoordinated way due to the absence of strategic thinking as regards the relationship between each particular organisation and the dimensions of CSR. Consequently, our findings exhibit where organisations can reasonably expect to reach achievements in CSR if these standards are implemented in a suitable fashion, and where it is necessary to resort to other types of approaches. Likewise, it has been shown how CSR actions can be implemented without the need to raise the level of impact on CSR artificially (for example by implementing and certifying management systems that lack any direct relationship with the impact of the organisation on the 
dimensions of CSR) but instead through a stricter application of the value that the EFQM Model has in CSR.

\subsection{LIMITATIONS AND FUTURE LINES OF RESEARCH}

The research process entails the need to make a number of choices about different aspects of the goals, the methodology and the subjects of study. It can therefore be said that the limitations are inherent to the process and, in many cases, are the origin of future lines of research. One of the limitations of this study is to be found in the very nature of the process of EFQM recognition, which does not ensure uniformity in all aspects of management, due to its being the sum of the scores from the assessment of the actions that are implemented. Because the research is focused on a case study, it presents the limitations that are inherent to this methodology. Therefore factors that can be chosen by the researcher, such as geographical location, size, sector and ownership, can have an important influence on the characteristics of the CSR practices that are found.

Throughout the research process lines of work have arisen that it has not been possible to address but which are considered to be of interest for research in the near future. We propose that the relationship between the model of Maon et al. (2010) and other Excellence models, such as the case of Malcolm Baldridge and the Deming Prize, should be tested, both theoretically and empirically, since this would make it possible to determine the contribution made by QM to the implementation of CSR. As a way to avoid the limitations of a case study, in future research the intention is to conduct a study using a wider group of organisations. Thus, it could make sense to carry out a study with a larger number of cases to increase the number of organisations at each level of EFQM recognitions, to conduct a study of all the organisations in the same territory or to perform an in-depth analysis of organisations from the same sector. 


\section{REFERENCES}

Agudo, J.M., Garcés, C., Salvador, M., 2012. "Social responsibility practices and evaluation of corporate social performance", Journal of Cleaner Production, 35 November, pp. 25-38.

Ahmed, N. U., Montagno, R.V., Flenze, R.J., 1998. "Organizational Performance and Environmental Consciousness: an empirical study". Management Decision, 36(2), pp. 5762.

Ahmed, A.M., Yang, J.B., Dale, B.G., 2003. "Self-assessment methodology: The route to business excellence". Quality Management Journal, 10(1), pp. 43-57.

Alfaro, J.J., Carot, J.M., Rodríguez, R., Jabaloyes, J.M., 2011. "Seeking organisational excellence by using the information coming from the EFQM excellence model as starting point: application to a real case", Total Quality Management \& Business Excellence, 22(8), pp. 853-868.

Araújo, M., Sampaio, P. 2014. "The path to excellence of the Portuguese organisations recognised by the EFQM model", Total Quality Management \& Business Excellence, 2(56), pp. 427-438.

Argandoña, A., von Weltzein, H., 2009. "Corporate social responsibility: One size does not fit all. Collecting evidence from Europe", Working Paper WP-834, IESE Business School.

Asif, M., Searcy, C., Garvare, R., Ahmad, N., 2011. "Including sustainability in business excellence models", Total Quality Management \& Business Excellence, 22(7), pp. 773-786.

Avlonas, N. and Swannick, J., 2009. "Developing Business Excellence while delivering Responsible Competitveness", In Jonker, J. and Eskildsen, J.: Management Models for the Future. Springer, 171-184.

Balbastre, F., Cruz, S., Moreno, M. (2005). "A model of quality management self-assessment: an exploratory research", International Journal of Quality \& Reliability Management, 22(5), pp. 432-51.

Balbastre, F. (2006), "TQM application through self-assessment and learning: some experiences from two EQA applicants", Quality Management Journal, 13 (1), pp. 7-21. 
Bendell, J., Miller, A., Wortmann, K., 2011. "Public policies for scaling corporate responsibility standards. Expanding collaborative governance for sustainable development". Sustainability Accounting, Management and Policy Journal, 2(2), pp. 263-293.

Berger, I.E., Cunningham, P. and Drumwright, M.E. (2007). "Mainstreaming corporate social responsibility: developing markets for virtue", California Management Review, 49, pp. $132-157$.

Black, S.A., Crumley, H.C., 1997. "Self-assessment: what's in it for us?" Total Quality Management, 8(2), pp. 96-9.

Blombäck, A., Wigren, C., 2009. "Challenging the importance of size as determinant for CSR activities", Management of Environmental Quality: An International Journal, 20(3), pp. $255-270$.

Bou, J.C., Escrig, A.B., Roca, V., Beltrán, I., 2009. “An empirical assessment of the EFQM Excellence Model: Evaluation as a GC framework relative to the MBNQA Model", Journal of Operations Management, 27(1), pp. 1-22.

Calvo de Mora, A, Leal, A., Roldán, J.L., 2006. "Using enablers of the EFQM model to manage institutions of higher education”. Quality Assurance in Education, 14(2), pp. 99 - 122.

Calvo-Mora, A., Navarro-García, A., \& Periañez-Cristobal, R. (2015). "Project to improve knowledge management and key business results through the EFQM excellence model." International Journal of Project Management, 33(8), pp. 1638-1651.

Carroll, A. B., 1979. "A three-dimensional conceptual model of corporate performance", The Academy of Management Review, 4, p 17.

Castka, P., Bamber, C.J., Bamber, D. J., Sharp, J.M. 2004a. "Integrating corporate social responsibility (CSR) into ISO management systems - in search of a feasible CSR management system framework", The TQM Magazine, 16(3), p. 216-224.

Castka, P., Balzarova, M., Bamber, C., Sharp, J., 2004b. "How can SMEs effectively implement the CSR agenda - a UK case study perspective", Corporate Social Responsibility and Environmental Management, 11(3), pp. 140-149. 
Castka, P., Balzarova, M.A., 2007. “A Pathway to 'CSR Excellence': the roles of ISO 9000 and ISO 26000", en 12-ICIT 9-11/4/07 in RoC Going for Gold Quality Standards: ISO 9000, etc. Paper $n^{\text {o: }: 02-05 . ~}$

CEG (Excellence in Management Club, Club Excelencia en Gestión), 2011. VIII Report of Excellence en Spain, VIII Informe de la Excelencia en España 2011.

CEG (Excellence in Management Club, Club Excelencia en Gestión), 2014. General Guide for Recognisement, v 1.1, Guía General del Reconocimiento a la Excelencia v 1.1.Dale, B.G., Lascelles, D.M., 1997. “Total quality management adoption: revisiting the levels”, The TQM Magazine, 9(6), pp. 418 - 428.

Dale, A., Hill, S.B., 2002. "At the Edge: Sustainable Development in the 21st Century", 2nd ed., Sustainability and the Environment Series, Vol. 232, University of British Columbia Press, Vancouver.

Done, A., Voss, C., Rytter, N.G., 2011. "Best practice interventions: Short-term impact and longterm outcomes", Journal of Operations Management, 29(5), pp., 500-513.

EFQM, 2012. EFQM Model for Business Excellence, EFQM, Brussels.

EFQM, 2015. EFQM Framework for Sustainability, http://www.efqm.org/efqm-framework-forsustainability

Eisenhardt, K.M., 1989. "Building theories from Case Study research", Academy of Management Review, 4(4), pp. 532-550.

Erhard, W., Jensen, M., Zaffron, S., 2009. "Integrity: A Positive Model that Incorporates the Normative Phenomena of Morality, Ethics and Legality". Harvard Business School NOM Working Paper No. 06-11

Graafland, J. J., 2002. "Corporate Social Responsibility and Family Business", Paper presented at the Research Forum of the Family Business Network 13th Annual Conference. Helsinki, Finland.

Gjølberg, M., 2009. "Measuring the immeasurable? Constructing an index of CSR practices and CSR performance in 20 countries", Scandinavian Journal of Management, 25, pp. 10-22. 
Isaksson, R., 2006. "Total quality management for sustainable development: Process based system models”, Business Process Management Journal, 12 (5). pp. 632-645.

Heras, I., Arana, G., Casadesús, M., 2006. "A Delphi study on motivation for ISO 9000 and EFQM". The International Journal of Quality \& Reliability Management. 23(7), pp. 807827

Jacobs, B., Suckling, S., 2007. "Assessing customer focus using the EFQM Excellence Model: a local government case".The TQM Magazine, 19(4), pp.368 - 378.

Jasiulewicz-Kaczmarek, M., 2014. "Is Sustainability development an issue for Quality Managment?", Foundations of Management, 6(2), pp. 51-66.

Jayamaha, N., Grigg, N., \& Mann, R. 2009. "A study of the validity of three major business excellence models in the Asia Pacific region", Total Quality Management \& Business Excellence, 20(11), 1213-1227.

Kok, P., van der Wiele, T.; McKenna, R.; Brown, A., 2001. “A Corporate Social Responsibility audit within a Quality Management Framework”, Journal of Business Ethics, 31, 285-297.

Maas, S., Reniers, G., 2013. "Development of a CSR model for practice: connecting five inherent areas of sustainable business", Journal of Cleaner Production, 64, pp. 104-114.

Maon, F., Lindgreen, A., Swaen, V., 2010. “Organizational Stages and Cultural Phases: A Critical Review and a Consolidative Model of Corporate Social Responsibility Development”, International Journal of Management Review, 12(1), pp. 20-38.

Marimón, F., Heras, I., Casadesús, M., 2009. "ISO 9000 and ISO 14000 standards: A projection model for the decline phase". Total Quality Management \& Business Excellence, 20(1), pp. $1-21$.

Martín-Castilla, J.I., Rodriguez-Ruíz, O., 2008. "EFQM model: knowledge governance and competitive advantage”. Journal of Intellectual Capital, 9(1), pp. 133-156.

Maxwell, J. A., 1998. "Designing a Qualitative Study” en Bickman, L., Rog, D. J. (eds.): Handbook of Applied Social Research Methods, Sage Publications, Thousand Oaks, pp. 69100. 
McAdam, R., Leonard, D., 2003. "Corporate social responsibility in a total quality management context: opportunities for sustainable growth", Corporate Governance, 3 (4), pp. 36-45.

Mohammad, M., Mann, R., Grigg, N., \& Wagner, J. P. 2011. "Business Excellence Model: An overarching framework for managing and aligning multiple organisational improvement initiatives". Total Quality Management \& Business Excellence, 22(11), 1213-1236.

Moratis, L. (2015). "Standardizing a Better World? Essays and Critical Reflections on the ISO 26000 Standard for Corporate Social Responsibility." Retrieved from: http://pplus.nl/resources/articlefiles/LarsMoratis.pdf

NEN, 2011. Guidance on self declaration NEN-ISO 26000. Nederlands Normalisatie-instituut Retrieved from: http://www.nen.nl/web/file?uuid=f4b43aaf-de39-431f-95058d3ca644b2e1\&owner=ccdd2a27-7f28-43b1-a3cb-d01e2bf2a56a\&contentid=150019.

Patton, M. Q., 1990. Qualitative evaluation and research methods. SAGE Publications, inc.

Pedersen, E. R., Neergaard, P., 2008. "From periphery to center: how CSR is integrated in mainstream performance management frameworks”. Measuring Business Excellence, 12(1), pp. 4-12.

Rowley, T., Berman, S., 2000. “A Brand New Brand of Corporate Social Performance”, Business and Society, 39(4), pp. 397-418.

Samuelsson, P., Nilsson, L.-E., 2002. "Self-assessment practices in large organizations: Experiences from using the EFQM excellence model.” International Journal of Quality \& Reliability Management, 19(1), pp. 10-23.

Schreck, P., 2011. "Reviewing the Business Case for Corporate Social Responsibility: New Evidence and Analysis", Journal of Business Ethics, 103(2), pp. 167-188.

Sweeney, L., 2007. "Corporate social responsibility in Ireland: Barriers and opportunities Experienced by SMEs when undertaking CSR", Corporate Governance, 7(4), pp. 516-523.

Taneja, S.S., Taneja, P.K., Gupta, R.K., 2011. "Researches in Corporate Social Responsibility A Review of Shifting Focus, Paradigms, and Methodologies", Journal of Business Ethics, 101(3), pp. 343-364. 
Tarí, J.J., 2010. "Self-assessment processes: the importance of follow-up for success", Quality Assurance in Education, 18(1), pp. 19-33.

Tarí, J.J., 2011. "Research into Quality Management and Social Responsibility", Journal of Business Ethics, 102(4), pp. 623-638.

Tokarcikova, E., Bartosova, V., Ponisciakova, O., 2014. "Corporate Social Responsibility Reporting”, Journal of Information, Control and Management Systems, Vol. 12, No. 2, pp. 211-220

Van Aken, E.M., Letens, G., Coleman, G.D., Farris, J., \& Van Goubergen, D. (2005). “Assessing maturity and effectiveness of enterprise performance measurement systems". International Journal of Productivity and Performance Management, 54(5/6), 400-418.

Van der Wiele, T., Brown, A., Millen, R, Whelan, D., 2000. "Improvement in Organizational Performance and Self-Assessment Practices by Selected American Firms". Quality Management Journal, 7(4), pp. 8-22.

Van der Wiele, T., Williams, A.R.T., Dale, B.G., Carter, G., Kolb, F., Luzon, D.M., Schmidt, A., Wallace, M., 1996. "Self-assessment: a study of progress in Europe's leading organization in quality management practices", International Journal of Quality \& Reliability Management, 13, pp. 84-104.

Van Marrewijk, M., 2003, "Concepts and Definitions of CSR and Corporate Sustainability: Between Agency and Commitment”, Journal of Business Ethics, 44(2/3), pp. 95-105.

Van Marrewijk, M., Werre, M., 2003. "Multiple Levels of Corporate Sustainability", Journal of Business Ethics, 44(2/3), pp. 107 - 119.

Vives, A., 2006. "Social and environmental responsibility in small and medium enterprises in Latin America”. Journal of Corporate Citizenship, 21, pp. 39-50.Waddock, S.A., Bodwell, C., 2004. "Managing responsibility: what can be learnt from the quality movement?" California Management Review, Vol. 47(1), pp. 25-37

Waddock, S.A., Graves, S.B., 1997. "The Corporate Social Performance-Financial Performance Link.” Strategic Management Journal, 18(4), pp. 303-319. 
Waddock, S.A., Bodwell, C., 2002. "From TQM to TRM: Total Responsibility Management Approaches." Journal of Corporate Citizenship, 7 pp. 113-126.

Yin R.K., 1994. Case study research: design and methods. California: Sage Publications Inc.

Yin, R. K., 1998. The Abridged Version of Case Study Research, en Bickman, L., Rog, D. J. (eds.): Handbook of Applied Social Research Methods, Sage Publications, Thousand Oaks, pp. 229-259.

Figure 1: Criteria of the EFQM Excellence Model

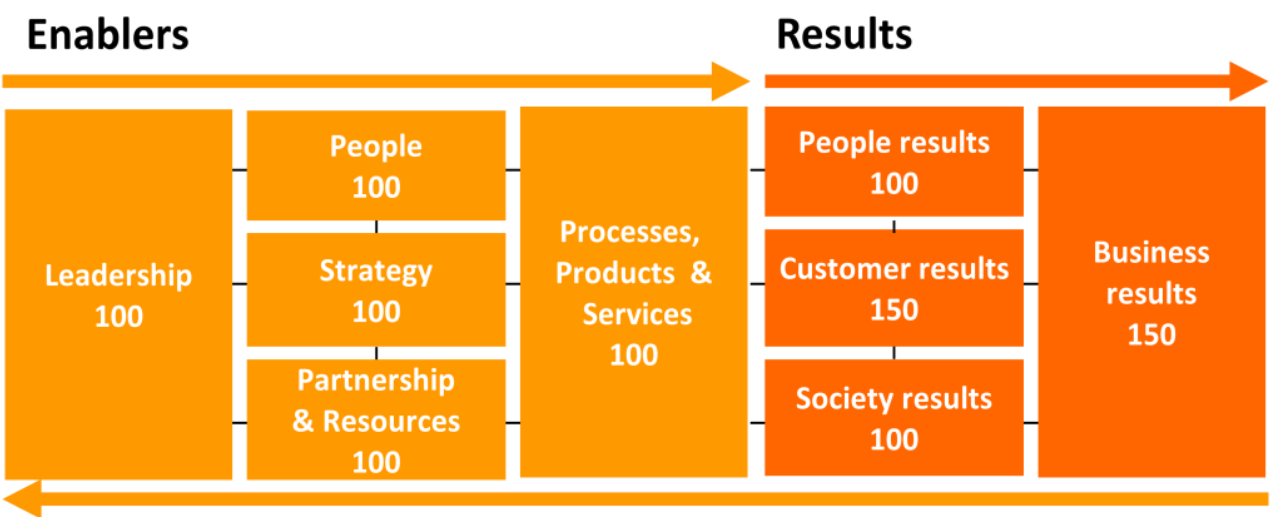

Learning, Creativity and Innovation

Source: Adapted from the EFQM 2012 
Table 1 The Consolidative Model of CSR Development

\begin{tabular}{|c|c|c|c|c|c|c|c|c|c|c|c|c|c|}
\hline \multirow{3}{*}{$\begin{array}{l}\text { CSR } \\
\text { Cultural } \\
\text { Phase }\end{array}$} & \multirow{3}{*}{$\begin{array}{l}\text { Stage of CSR } \\
\text { development }\end{array}$} & \multirow{3}{*}{$\begin{array}{c}\text { CSR view/ } \\
\text { prominence } \\
\text { in } \\
\text { organisational } \\
\text { culture }\end{array}$} & \multicolumn{11}{|c|}{ Dimensions of CSR development } \\
\hline & & & \multicolumn{3}{|c|}{ Knowledge and attitudinal dimensions } & \multicolumn{4}{|c|}{ Strategic dimensions } & \multicolumn{4}{|c|}{ Tactical and operational dimensions } \\
\hline & & & \begin{tabular}{|c|} 
Organisational \\
sensitivity to \\
CSR issues
\end{tabular} & $\begin{array}{c}\text { Driver of CSR } \\
\text { initiatives } \\
\text { development }\end{array}$ & $\begin{array}{c}\text { Support of } \\
\text { top } \\
\text { management }\end{array}$ & $\begin{array}{c}\text { Social } \\
\text { responsiveness }\end{array}$ & $\begin{array}{c}\text { Rationale } \\
\text { behind CSR } \\
\text { initiatives }\end{array}$ & $\begin{array}{c}\text { Performance } \\
\text { objectives }\end{array}$ & $\begin{array}{l}\text { Transparency } \\
\text { and reporting }\end{array}$ & $\begin{array}{l}\text { Stakeholders } \\
\text { relationship }\end{array}$ & $\begin{array}{l}\text { Resources } \\
\text { commitment }\end{array}$ & $\begin{array}{l}\text { Structuring } \\
\text { of CSR } \\
\text { initiatives }\end{array}$ & $\begin{array}{l}\text { Coordination of } \\
\text { CSR issues }\end{array}$ \\
\hline $\begin{array}{l}\text { CSR } \\
\text { CULTURAL } \\
\text { RELUCTANCE }\end{array}$ & 1. Dismissing & $\begin{array}{l}\text { Winning at any } \\
\text { cost perspective/ } \\
\text { None }\end{array}$ & $\begin{array}{l}\text { Active } \\
\text { opposition to } \\
\text { CSR broader } \\
\text { than financial } \\
\text { benefits } \\
\end{array}$ & None & None & Rejection & None & None & Black-box & $\begin{array}{l}\begin{array}{l}\text { Purely } \\
\text { contractual }\end{array}\end{array}$ & None & None & None \\
\hline \multirow{3}{*}{$\begin{array}{l}\text { CSR } \\
\text { CULTURAL } \\
\text { GRASP }\end{array}$} & 2. Self-protecting & $\begin{array}{l}\text { Reputation \& } \\
\text { Philanthropy } \\
\text { perspective/ CSR } \\
\text { as marginal }\end{array}$ & 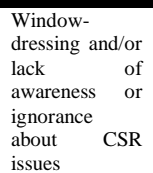 & $\begin{array}{l}\text { Lack of CSR- } \\
\text { orientation } \\
\text { perceived as } \\
\text { potentially } \\
\text { harming } \\
\text { business }\end{array}$ & $\begin{array}{l}\text { Piecemeal } \\
\text { involvement }\end{array}$ & Strong defence & $\begin{array}{l}\text { Limitation } \\
\text { of } \\
\text { potentially } \\
\text { harming and } \\
\text { uncontrolled } \\
\text { criticisms }\end{array}$ & $\begin{array}{l}\text { Resolution of } \\
\text { problems as they } \\
\text { occur }\end{array}$ & $\begin{array}{l}\text { Justifying } \\
\text { posture }\end{array}$ & Punctual & $\begin{array}{l}\text { Budget for } \\
\text { problems as } \\
\text { they occur }\end{array}$ & Activities & $\begin{array}{l}\text { Public relations } \\
\text { concern }\end{array}$ \\
\hline & $\begin{array}{l}\text { 3. Compliance- } \\
\text { seeking }\end{array}$ & $\begin{array}{l}\text { Requirements } \\
\text { perspective/ CSR } \\
\text { as worthy of } \\
\text { interest }\end{array}$ & $\begin{array}{l}\text { Growing } \\
\text { awareness of } \\
\text { CSR-related } \\
\text { troubles to be } \\
\text { avoided }\end{array}$ & $\begin{array}{l}\text { CSR perceived } \\
\text { as a duty and an } \\
\text { obligation } \quad- \\
\text { Focus } \\
\text { restricted on } \\
\text { Requisites }\end{array}$ & $\begin{array}{l}\text { Involvement } \\
\text { in theory/ } \\
\text { professed }\end{array}$ & $\begin{array}{l}\text { Light defence / } \\
\text { Reaction }\end{array}$ & $\begin{array}{l}\text { Compliance } \\
\text { objectives }\end{array}$ & $\begin{array}{l}\text { Minimisation of } \\
\text { harmful } \\
\text { externalities/ } \\
\text { Respect of } \\
\text { evolving norms } \\
\text { and regulatory } \\
\text { requirements }\end{array}$ & $\begin{array}{l}\text { Internal } \\
\text { reporting/ } \\
\text { Legal } \\
\text { disclosure } \\
\text { posture }\end{array}$ & Unilateral & $\begin{array}{l}\text { Limited } \\
\text { minimal } \\
\text { funding }\end{array}$ & Policies & Functional \\
\hline & $\begin{array}{l}\text { 4. Capability- } \\
\text { seeking/ }\end{array}$ & $\begin{array}{l}\text { Stakeholder } \\
\text { management } \\
\text { perspective/ } \\
\text { CSR } \\
\text { influential as }\end{array}$ & $\begin{array}{l}\text { Growing } \\
\text { awareness of } \\
\text { CSR-related } \\
\text { advantages to } \\
\text { be gained }\end{array}$ & $\begin{array}{l}\text { CSR perceived } \\
\text { as a duty and an } \\
\text { obligation - } \\
\text { Focus on } \\
\text { Fonfluent } \\
\text { expectations }\end{array}$ & $\begin{array}{l}\text { Fair } \\
\text { involvement/ } \\
\text { supportive }\end{array}$ & $\begin{array}{l}\text { Accommodation/ } \\
\text { response }\end{array}$ & $\begin{array}{l}\text { License to } \\
\text { operate }\end{array}$ & $\begin{array}{l}\text { Anticipating new } \\
\text { requirements and } \\
\text { expectations/ } \\
\text { Identification of } \\
\text { profitable niches } \\
\text { for CSR initiatives }\end{array}$ & $\begin{array}{l}\text { Internal } \\
\text { reporting/ } \\
\text { Selective } \\
\text { disclosure } \\
\text { posture }\end{array}$ & Interactive & $\begin{array}{l}\text { Generally } \\
\text { sufficient but } \\
\text { inconstant } \\
\text { funding }\end{array}$ & $\begin{array}{l}\text { Plans of } \\
\text { action }\end{array}$ & Multi-functional \\
\hline \multirow{3}{*}{$\begin{array}{l}\text { CSR } \\
\text { CULTURAL } \\
\text { EMBEDMENT }\end{array}$} & 5. Caring/ & $\begin{array}{l}\text { Stakeholder } \\
\text { dialogue } \\
\text { perspective/ CSR } \\
\text { as embodied }\end{array}$ & $\begin{array}{l}\text { Knowledgeable } \\
\text { CSR awareness }\end{array}$ & $\begin{array}{l}\text { CSR perceived } \\
\text { as important as } \\
\text { such }\end{array}$ & Commitment & Adaptation & $\begin{array}{l}\text { Competitive } \\
\text { advantage }\end{array}$ & $\begin{array}{l}\text { Active } \\
\text { management of } \\
\text { CSR-related } \\
\text { issues/Definition } \\
\text { of business-wide } \\
\text { opportunities }\end{array}$ & $\begin{array}{l}\text { Public } \\
\text { reporting } \\
\text { posture }\end{array}$ & $\begin{array}{l}\text { Reciprocal } \\
\text { influence }\end{array}$ & $\begin{array}{l}\text { Dependable } \\
\text { funding }\end{array}$ & Programmes & Cross-functional \\
\hline & 6. Strategising/ & $\begin{array}{l}\text { Sustainability } \\
\text { perspective/ CSR } \\
\text { as prevailing }\end{array}$ & $\begin{array}{l}\text { Leadership } \\
\text { objectives on } \\
\text { CSR-related } \\
\text { issues }\end{array}$ & $\begin{array}{l}\text { CSR perceived } \\
\text { as inexorable } \\
\text { direction to take }\end{array}$ & $\begin{array}{l}\text { Sound } \\
\text { commitment }\end{array}$ & $\begin{array}{l}\text { Strategic } \\
\text { proactivity }\end{array}$ & $\begin{array}{l}\text { Value } \\
\text { proposition }\end{array}$ & $\begin{array}{l}\text { Leading the } \\
\text { pack/Development } \\
\text { of sustainable } \\
\text { business leverages } \\
\text { through CSR } \\
\text { initiatives }\end{array}$ & $\begin{array}{l}\text { Certified } \\
\text { reporting } \\
\text { posture }\end{array}$ & Collaborative & $\begin{array}{l}\text { Substantial } \\
\text { funding }\end{array}$ & Systems & $\begin{array}{l}\text { Organisational } \\
\text { realignment }\end{array}$ \\
\hline & 7. Transforming/ & $\begin{array}{l}\text { Change the game } \\
\text { perspective/ CSR } \\
\text { as ingrained }\end{array}$ & $\begin{array}{l}\text { CSR as an } \\
\text { internalised } \\
\text { management } \\
\text { ideology }\end{array}$ & $\begin{array}{l}\text { CSR as the only } \\
\text { alternative } \\
\text { considering } \\
\text { universal mutual } \\
\text { interdependency }\end{array}$ & Devotion & Proactivity & $\begin{array}{l}\text { Enlarged } \\
\text { finality } \\
\begin{array}{l}\text { Societal } \\
\text { change }\end{array}\end{array}$ & $\begin{array}{ll}\begin{array}{l}\text { Diffusion } \\
\text { expertise/ }\end{array} & \text { of } \\
\text { Maximisation } & \text { of } \\
\text { positive } & \\
\text { externalities } & \end{array}$ & $\begin{array}{l}\text { Fully } \\
\text { transparent } \\
\text { posture }\end{array}$ & $\begin{array}{l}\text { Joint } \\
\text { innovation }\end{array}$ & $\begin{array}{l}\text { Open-ended } \\
\text { funding and } \\
\text { resource } \\
\text { commitment }\end{array}$ & $\begin{array}{l}\text { Core } \\
\text { integration - } \\
\text { CSR as } \\
\text { business as } \\
\text { usual }\end{array}$ & Institutionalisation \\
\hline
\end{tabular}

Source: Authors' own creation based on Maon et al. (2010)

Table 2: Data, implemented initiatives and persons interviewed in the case studies 


\begin{tabular}{|c|c|c|c|}
\hline \multirow{2}{*}{ ORGANISATION } & \multicolumn{2}{|r|}{ IMPLEMENTED INITIATIVES AND RELATED DOCUMENTS REVIEWED } & $\begin{array}{c}\text { PERSONS } \\
\text { INTERVIEWED }\end{array}$ \\
\hline & YEAR implemented & DOCUMENTS REVIEWED & \multirow{6}{*}{$\begin{array}{l}\text { - Managing Director, } \\
\text { - Director of Quality and the } \\
\text { Environment, Metallurgy, } \\
\text { Quality, Prevention and } \\
\text { Environment Manager } \\
\text { - HR Manager } \\
\text { - Two welders, one from each } \\
\text { work centre. }\end{array}$} \\
\hline \multirow{5}{*}{$\begin{array}{l}\text { Asturfeito: Activity: capital } \\
\text { goods } \\
\text { Employees: } 140\end{array}$} & 2000 & Definition of Mission, Vision, Corporative Values and its commitment with CSR. ISO 9001 certificate. & \\
\hline & 2006 & UNE 166002 (Certification of the R\&D Management System). & \\
\hline & 2007 & OHSAS 18001 certificate. & \\
\hline & 2010 & $\begin{array}{l}\text { Recognition EFQM 200+: Self-assessment documents, External assessment report. } \\
\text { UN Global Compact participant. } \\
\text { Sustainability Report in accordance with Guideline G3 of the GRI, level C. } \\
\end{array}$ & \\
\hline & 2011 & ISO 14001 certificate. & \\
\hline \multirow{10}{*}{$\begin{array}{l}\text { CTAI Ingeniería Consultants, } \\
\text { Training and Engineering in } \\
\text { industrial } \\
\text { Employees: } 35\end{array}$} & 1996 & Definition of the Mission, Vision and Values. DIRFO + (Quality standard for training organisations) & \multirow{10}{*}{$\begin{array}{l}\text { - General Manager } \\
\text { - Director of Quality, } \\
\text { Innovation and Prevention } \\
\text { - Engineer from the area of } \\
\text { Industrial Control. }\end{array}$} \\
\hline & 2000 & ISO certificate. & \\
\hline & 2002 & REPRO (Accreditation of suppliers for the energy and petrochemical sectors) & \\
\hline & 2004 & 1st EFQM Self-Assessment & \\
\hline & 2005 & EFQM 200+: Self-assessment documents, External assessment report. & \\
\hline & 2006 & 2nd EFQM Self-Assessment & \\
\hline & 2007 & 3rd EFQM Self-Assessment & \\
\hline & 2008 & EFQM 300+: Self-assessment documents, External assessment report. & \\
\hline & 2009 & 4th EFQM Self-Assessment & \\
\hline & 2010 & $\begin{array}{l}\text { ISO } 27001 \text { certificate. } \\
\text { EFQM } 300+\text { : Self-assessment documents, External assessment report. }\end{array}$ & \\
\hline \multirow{6}{*}{ 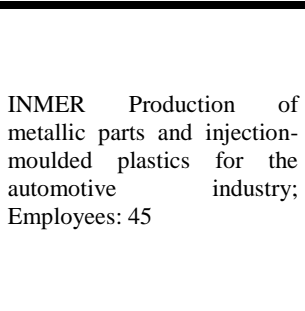 } & 1997 & $\begin{array}{l}\text { Definition of the Mission, Vision and Values within the Manual of Values and Competencies of the firm. } \\
\text { ISO } 9001 \text { certificate. }\end{array}$ & \multirow{6}{*}{$\begin{array}{l}\text { - Managing Director } \\
\text { - Director Quality } \\
\text { - Assistant Director of Quality } \\
\text { - Manager of the Engineering } \\
\text { Department Technician } \\
\text { specialised in presses } \\
\text { - Technician specialised in } \\
\text { injectors. }\end{array}$} \\
\hline & 1998 & QS 9000 certificate. & \\
\hline & 2006 & ISO TS 16949 certificate; Impulso Prize awarded by the Local Government of the Principality of Asturias & \\
\hline & 2007 & EFQM 200+: Self-assessment documents, External assessment report. & \\
\hline & 2009 & $\begin{array}{l}\text { Impulso Prize awarded by the Local Government of the Principality of Asturias } \\
\text { EFQM } 400+\text { (implementation of: Strategy, Strategic Map, Integration Plan and Relevant Indicators): Self-assessment documents, External } \\
\text { assessment report. }\end{array}$ & \\
\hline & 2011 & EFQM 400+: Self-assessment documents, External assessment report. & \\
\hline \multirow{12}{*}{$\begin{array}{l}\text { Autoridad Portuaria de Gijón, } \\
\text { port of general interest; } \\
\text { Employees: } 191\end{array}$} & 1999 & Definition of the Mission, Vision and Values. Beginning of a QM System & \multirow{12}{*}{$\begin{array}{l}\text { - General Manager } \\
\text { - Assistant General Manager } \\
\text { (Technical Sub-Director). } \\
\text { - Director of Quality } \\
\text { - Director of Environmental } \\
\text { Affairs } \\
\text { - Director of Occupational } \\
\text { Health and Safety } \\
\text { - Director of HR with } \\
\text { corporate attributions in } \\
\text { CSR. } \\
\text { - Two officials from the } \\
\text { Quality Department } \\
\text { - One official from the } \\
\text { Environmental Affairs } \\
\text { Department. }\end{array}$} \\
\hline & 2000 & Constitution of the Environment and Quality Management Committees & \\
\hline & 2000 & ISO 9001 certificate; 1st EFQM Self-Assessment & \\
\hline & 2002 & 1st EFQM Report, Prize for Quality in the General State Administration III & \\
\hline & 2003 & EFQM 300+: Self-assessment documents, External assessment report. & \\
\hline & 2004 & $\begin{array}{l}\text { Awarded the Distinction of Recognition of Comprehensive System of Quality Tourist Destination (SICTED), 2nd EFQM Self-Assessment, } \\
\text { Constitution of the Port Community Association }\end{array}$ & \\
\hline & 2005 & Dirigentes Prize for the Best Business Management & \\
\hline & 2006 & $\begin{array}{l}\text { EFQM 400+: Self-assessment documents, External assessment report. } \\
\text { Standard ISO } 9001 \text { of the Port Community Association, Certificate of the Maritime Navigation Assistance Service, 2nd SICTED, Impulso } \\
\text { Prize awarded by the Government of the Principality of Asturias }\end{array}$ & \\
\hline & 2007 & ISO 14001 certificate; 3rd EFQM Self-Assessment & \\
\hline & 2008 & EFQM 500+ (4th EFQM Report): Self-assessment documents, External assessment report. & \\
\hline & 2010 & $\begin{array}{l}\text { Escoba de Plata Prize, Flexible Company Prize, ESPO Prize to the best Port-Town project } \\
\text { EFQM 500+ (4th Self-Assessment, 5th EFQM Report): Self-assessment documents, External assessment report. }\end{array}$ & \\
\hline & 2011 & UN Global Compact participant; UNE 166002:2006 certificate. & \\
\hline
\end{tabular}


Source: Authors' own creation based on information provided by organisations

Table 3: Evidence found and organisations' self-assessment of their CSR activities in the Knowledge and Attitudinal dimensions

\begin{tabular}{|c|c|c|c|}
\hline \multirow{3}{*}{$\begin{array}{l}\text { Stage of CSR } \\
\text { development }\end{array}$} & \multicolumn{3}{|c|}{ Dimensions of CSR development } \\
\hline & \multicolumn{3}{|c|}{ Knowledge and attitudinal dimensions: evidences. } \\
\hline & Organisational sensitivity to CSR issues & Driver of CSR initiatives development & Support of top management \\
\hline 1. Dismissing & Active opposition to CSR broader than financial benefits & None & None \\
\hline $\begin{array}{l}2 . \quad \text { Self- } \\
\text { protecting }\end{array}$ & $\begin{array}{l}\text { Window-dressing and/or lack of awareness or ignorance } \\
\text { about CSR issues }\end{array}$ & $\begin{array}{l}\text { Lack of CSR-orientation perceived as potentially harming } \\
\text { business }\end{array}$ & Piecemeal involvement \\
\hline $\begin{array}{l}\text { 3. Compliance- } \\
\text { seeking }\end{array}$ & $\begin{array}{l}\text { Growing awareness of CSR-related troubles to be } \\
\text { avoided. } \\
\text { Corporate values in line with CSR have been defined. } \\
\text { EFQM assessment evidenced that: environment should } \\
\text { be defined as an issue that must be tackled; a more } \\
\text { thorough definition of the company culture must be } \\
\text { carried out; a strategic review process must include } \\
\text { information for more stakeholders; a comprehensive } \\
\text { approach to CSR issues is needed. }\end{array}$ & $\begin{array}{l}\text { CSR perceived as a duty and an obligation - Focus on } \\
\text { restricted Requisites }\end{array}$ & $\begin{array}{l}\text { Theoretical/professed involvement: top management } \\
\text { fully believe that high ethical standards are needed } \\
\text { although this is something that is assumed and } \\
\text { evaluated but not explicitly promoted by direct } \\
\text { actions. EFQM assessment showed that tools to } \\
\text { review leadership must be implemented }\end{array}$ \\
\hline $\begin{array}{l}\text { 4. Capability- } \\
\text { seeking }\end{array}$ & $\begin{array}{l}\text { Growing awareness of CSR-related advantages to be } \\
\text { gained: certified standards, such as ISO 9001, ISO } \\
14001 \text { or OHSAS 18001, are not sufficient guarantee for } \\
\text { clients, but provide a differentiation from would-be } \\
\text { competitors; Culture, Ethics Principles, and Corporate } \\
\text { Values of the company defined thanks to improvement } \\
\text { areas defined in EFQM assessment }\end{array}$ & \multirow{2}{*}{$\begin{array}{l}\text { CSR perceived as a duty and an obligation - Focus on } \\
\text { confluent expectations: ethics is viewed as a valuable } \\
\text { asset, one that must be exercised by all employees, but } \\
\text { this attitude is not supported by more advanced } \\
\text { approaches }\end{array}$} & \multirow{2}{*}{$\begin{array}{l}\text { Fair/supportive involvement: top managemen } \\
\text { encourages CSR initiatives and was fostering the } \\
\text { three cycles of EFQM assessment }\end{array}$} \\
\hline $\begin{array}{l}\text { Committed to } \\
\text { Excellence } \\
200+\end{array}$ & $\begin{array}{l}\text { Growing awareness of CSR-related advantages to be } \\
\text { gained: } \\
\text { Corporate values and core competencies in line with } \\
\text { CSR have been defined; three cycles of EFQM } \\
\text { assessment have demonstrated the benefits of focusing } \\
\text { on employees as key stakeholders. EFQM assessment } \\
\text { showed that Mission, Vision and Values needed to be } \\
\text { updated }\end{array}$ & & \\
\hline \multirow{3}{*}{ 5. Caring } & \multirow{3}{*}{$\begin{array}{l}\text { Knowledgeable CSR awareness: } \\
\text { Corporate values and core competencies in line with } \\
\text { CSR have been defined and thoroughly developed; their } \\
\text { aim is to generate trust with society at large: Port } \\
\text { Community Association }\end{array}$} & $\begin{array}{l}\text { CSR perceived as important as such: UN Global Compact } \\
\text { participant. Sustainability Report in accordance with } \\
\text { Guideline G3 of the GRI, level C }\end{array}$ & $\begin{array}{l}\text { Commitment: allow employees to take actions in } \\
\text { business initiatives which provide the organisation } \\
\text { with value from both the external and the internal } \\
\text { perspectives }\end{array}$ \\
\hline & & $\begin{array}{l}\text { CSR perceived as important as such: three cycles of } \\
\text { EFQM assessment have demonstrated the impact of the } \\
\text { management of People interest as stakeholders }\end{array}$ & \multirow{2}{*}{$\begin{array}{l}\text { Commitment: support and promotion of all actions } \\
\text { undertaken by executives such as the Port } \\
\text { Community Association; Each group of stakeholders } \\
\text { has a member of the Board of Directors in charge of } \\
\text { their relationship; Leadership Behaviour } \\
\text { Competencies defined. EFQM Assessment showed } \\
\text { that ethical codes need support from top management } \\
\text { to be fully deployed; Leadership Model needs a } \\
\text { review; Leadership Model would be deployed to all } \\
\text { leaders, not just top managers }\end{array}$} \\
\hline & & $\begin{array}{l}\text { CSR perceived as important as such: Trust from society is } \\
\text { needed to be able to operate: Port Community Association }\end{array}$ & \\
\hline
\end{tabular}




\begin{tabular}{|l|l|l|l|}
\hline 6. Strategising & Leadership objectives on CSR-related issues & CSR perceived as inexorable direction to take & Sound commitment \\
\hline 7. Transforming & CSR as an internalised management ideology & $\begin{array}{l}\text { CSR as the only alternative considering universal mutual } \\
\text { interdependency }\end{array}$ & Devotion \\
\hline
\end{tabular}

Note: The organisations have been represented in colours. Thus, Asturfeito is shown in orange, CTAI Ingeniería in blue, INMER in green and APG in red.

Source: Authors' own creation based on Maon et al. (2010)

Table 4: Evidence found and organisations' self-assessment of their CSR activities in the Strategic dimensions

\begin{tabular}{|c|c|c|c|c|}
\hline \multirow{3}{*}{$\begin{array}{l}\text { Stage of CSR } \\
\text { development }^{\circ}\end{array}$} & \multicolumn{4}{|c|}{ Dimensions of CSR development } \\
\hline & \multicolumn{4}{|c|}{ Strategic dimensions: evidences } \\
\hline & Social responsiveness & Rationale behind CSR initiatives & Performance objectives & Transparency and reporting \\
\hline 1. Dismissing & Rejection & None & None & Black-box \\
\hline 2. Self-protecting & Strong defence & $\begin{array}{l}\text { Limitation of potentially harming and } \\
\text { uncontrolled criticisms }\end{array}$ & Resolution of problems as they occur & Justifying posture \\
\hline \multirow{2}{*}{ 3. Compliance-seeking } & \multirow{2}{*}{ Light defence / Reaction } & \multirow{2}{*}{$\begin{array}{l}\text { Compliance objectives: due to the fact that it } \\
\text { focuses on the hard dimensions of quality } \\
\text { standard ISO } 9001\end{array}$} & $\begin{array}{l}\text { Minimisation of harmful externalities/ Respect for evolving } \\
\text { norms and regulatory requirements: limited management } \\
\text { structure focused on hard dimensions of quality. A } \\
\text { sufficiently large number of resources to solve problems are } \\
\text { allocated to ensure that the issues do not happen again; } \\
\text { EFQM Assessment showed that more performance } \\
\text { objectives must be defined }\end{array}$ & \multirow{2}{*}{$\begin{array}{l}\text { Internal reporting/ Legal disclosure posture: } \\
\text { the seven cycles of EFQM assessment have } \\
\text { only been available to the workers and the } \\
\text { external assessors involved in it. EFQM } \\
\text { Assessment showed that more } \\
\text { communication channels with stakeholders } \\
\text { are needed }\end{array}$} \\
\hline & & & $\begin{array}{l}\text { Minimisation of harmful externalities/ Respect for evolving } \\
\text { norms and regulatory requirements: objective focused on } \\
\text { hard dimensions of quality. A sufficiently large number of } \\
\text { resources to solve problems are allocated to ensure that the } \\
\text { issues do not happen again. } \\
\text { EFQM Assessment showed that a systematic approach is } \\
\text { needed to manage environmental performance; all } \\
\text { performance indicators would be assessed regularly }\end{array}$ & \\
\hline $\begin{array}{l}\text { 4. Capability-seeking/ } \\
\text { Committed } \\
\text { Excellence 200+ }\end{array}$ & $\begin{array}{l}\text { Accommodation/ response: no dedicated tools to answer the } \\
\text { CSR concerns of external stakeholders. EFQM Assessment } \\
\text { showed that a more active role must be adopted by the } \\
\text { organisations in their relationship with society at large. }\end{array}$ & $\begin{array}{l}\text { License to operate: the soft dimensions of ISO } \\
9001 \text { and IIO TS } 16499 \text { have been developed } \\
\text { by three cycles of EFQM assessment }\end{array}$ & $\begin{array}{l}\text { Anticipating new requirements and expectations } / \\
\text { Identification of profitable niches for CSR initiatives: ISO } \\
14001 \text {, OHSAS 18001; EFQM assessment: Measurement of } \\
\text { client's perception; A new set of performance objectives } \\
\text { beyond the economic ones }\end{array}$ & $\begin{array}{l}\text { Internal reporting/ Selective disclosure } \\
\text { posture: the three cycles of EFQM } \\
\text { assessment has only be available to the } \\
\text { workers and the external assessors involved } \\
\text { in it but the } 2006 \text { and } 2009 \text { Impulso Prize } \\
\text { awarded by the Local Government of the } \\
\text { Principality of Asturias must be assessed for } \\
\text { a wider range of individuals from society at } \\
\text { large. EFQM Assessment showed that } \\
\text { internal communications systems must be } \\
\text { improved }\end{array}$ \\
\hline
\end{tabular}




\begin{tabular}{|c|c|c|c|c|}
\hline & $\begin{array}{l}\text { Accommodation/ response: no dedicated tools to answer the } \\
\text { CSR concerns of external stakeholders. EFQM Assessment } \\
\text { showed that a systematic approach is needed to manage } \\
\text { social performance }\end{array}$ & & $\begin{array}{l}\text { Anticipating new requirements and expectations I } \\
\text { Identification of profitable niches for CSR initiatives: ISO } \\
14001 \text {, OHSAS } 18001 \text { implemented. Involvement of } \\
\text { contractors in Quality, Environment and Health \& Safety } \\
\text { issues: Port Community. EFQM assessment showed that the } \\
\text { efficiency of the Port Community Association needs a } \\
\text { review; APG Performance data from other organisations are } \\
\text { needed }\end{array}$ & $\begin{array}{l}\text { Internal reporting/ Selective disclosure } \\
\text { posture: Sustainability Report in accordance } \\
\text { with Guideline G3 of the GRI not externally } \\
\text { validated; Lack of UN Global Compact } \\
\text { Communication on Progress report }\end{array}$ \\
\hline \multirow[b]{2}{*}{ 5. Caring/ } & $\begin{array}{l}\text { Adaptation: some dedicated tools to answer the CSR } \\
\text { concerns of stakeholders: ISO 14001, OHSAS 18001, CSR } \\
\text { Reporting }\end{array}$ & $\begin{array}{l}\text { Competitive advantage: based on the many } \\
\text { management tools implemented related with } \\
\text { CSR dimensions, i.e. ISO 9001, ISO } 14001 \text {, } \\
\text { OHSAS } 18001 \text { and GRI Sustainability Report }\end{array}$ & \multirow{2}{*}{$\begin{array}{l}\text { Active management of CSR-related issues/Definition of } \\
\text { business-wide opportunities }\end{array}$} & \multirow{2}{*}{$\begin{array}{l}\text { Collaboration and Transparency have been } \\
\text { defined as a core corporate value; Fou } \\
\text { cycles of EFQM assessment, the Por } \\
\text { Community Association; UN Globa } \\
\text { Compact participant in a range of activitie } \\
\text { that implies the need for accountability anc } \\
\text { transparency before stakeholders and society } \\
\text { at large. Draft of Sustainability Report it } \\
\text { accordance with Guideline G3 of the GRI }\end{array}$} \\
\hline & $\begin{array}{l}\text { Adaptation: } 24 \text { dedicated tools to gather information from } \\
\text { stakeholders; ISO 14001, OHSAS 18001, CSR Reporting }\end{array}$ & $\begin{array}{l}\text { Competitive advantage: besides the standards it } \\
\text { has implemented, ISO } 14001 \text {, OHSAS } 18001 \text {, } \\
\text { Port Community Association. Identification of } \\
\text { CSR as a competitive advantage that must be } \\
\text { achieved by its members }\end{array}$ & & \\
\hline 6. Strategising/ & Strategic proactivity & Value proposition & $\begin{array}{l}\text { Leading the pack/Development of sustainable business } \\
\text { leverages through CSR initiatives }\end{array}$ & Certified reporting posture \\
\hline 7. Transforming/ & Proactivity & Enlarged finality - Societal change & Diffusion of expertise/ Maximisation of positive externalities & Fully transparent posture \\
\hline
\end{tabular}

Note: The organisations have been represented in colours. Thus, Asturfeito is shown in orange, CTAI Ingeniería in blue, INMER in green and APG in red.

Source: Authors' own creation based on Maon et al. (2010)

Table 5: Evidence found and organisations' self-assessment of their CSR activities in the Tactical and operational dimensions

\begin{tabular}{|c|c|c|c|c|}
\hline \multirow{3}{*}{$\begin{array}{l}\text { Stage of CSR } \\
\text { development }^{\circ}\end{array}$} & \multicolumn{4}{|c|}{ Dimensions of CSR development } \\
\hline & \multicolumn{4}{|c|}{ Tactical and operational dimensions: evidences } \\
\hline & Stakeholders relationship & Resources commitment & Structuring of CSR initiatives & Coordination of CSR issues \\
\hline 1. Dismissing & Purely contractual & None & None & None \\
\hline 2. Self-protecting & Punctual & $\begin{array}{l}\text { Budget for problems as they occur: } \\
\text { Resources for CSR issues are allocated } \\
\text { only when it is absolutely necessary to } \\
\text { take action }\end{array}$ & $\begin{array}{l}\text { Activities: ISO 9001: actions focused } \\
\text { on the hard dimensions of quality }\end{array}$ & $\begin{array}{l}\text { Public relations concern: nobody is in charge } \\
\text { of just CSR issues or certified systems as the } \\
\text { only person responsible }\end{array}$ \\
\hline $\begin{array}{l}\text { 3. Compliance- } \\
\text { seeking }\end{array}$ & $\begin{array}{l}\text { Unilateral: traditional approach with stakeholders such as } \\
\text { society, employees and suppliers; EFQM assessment } \\
\text { showed that there was a need for new means of } \\
\text { communication; A new strategic planning that is more } \\
\text { focused on stakeholder relationships } \\
\text { Unilateral: traditional approach with stakeholders such as } \\
\text { society, employees and suppliers. EFQM assessment } \\
\text { evidenced the need for an employment climate survey; a } \\
\text { new strategic planning that is more focused on social, } \\
\text { legal and health \& safety issues; Stakeholders' point of } \\
\text { view must hold rather than clients'; A new strategy to } \\
\text { seek and assess alliances must be defined }\end{array}$ & Limited minimal funding & Policies & $\begin{array}{l}\text { Functional: Mainly focused on quality issues } \\
\text { (ISO 9001) }\end{array}$ \\
\hline $\begin{array}{l}4 . \quad \text { Capability- } \\
\text { seeking/ } \\
\text { Committed to } \\
\text { Excellence 200+ }\end{array}$ & $\begin{array}{l}\text { Interactive: Identification of } 8 \text { groups of stakeholders and } \\
\text { strategic lines towards them. Successive plans to interact } \\
\text { with stakeholder based on EFQM induced practices. } \\
\text { Impulso Prize for Excellence awarded by the Local } \\
\text { Government of the Principality of Asturias. }\end{array}$ & $\begin{array}{l}\text { Generally sufficient but inconstant } \\
\text { funding }\end{array}$ & $\begin{array}{l}\text { Plans of action: Improvement actions } \\
\text { derived from ISO 9001(both hard and } \\
\text { soft dimensions); Employment climate } \\
\text { survey. With items related to CSR } \\
\text { issues; Employment climate survey }\end{array}$ & $\begin{array}{l}\text { Functional: Focused on quality, health \& } \\
\text { safety issues but not coordinated (ISO 9001, } \\
\text { ISO 14001, OHSAS } 18001\end{array}$ \\
\hline
\end{tabular}




\begin{tabular}{|c|c|c|c|c|}
\hline & $\begin{array}{l}\text { EFQM Assessment showed that a systematic approach is } \\
\text { needed to manage information from the } \\
\text { Employment climate survey; EFQM Assessment: a } \\
\text { systematic approach is needed to collect information from } \\
\text { all stakeholders }\end{array}$ & & & $\begin{array}{l}\text { Functional: Focused on quality, health \& } \\
\text { safety issues but not col3ordinated (ISO } \\
9001 \text {, ISO 14001, OHSAS } 18001\end{array}$ \\
\hline \multirow{3}{*}{ 5. Caring/ } & \multirow{3}{*}{ Reciprocal influence } & $\begin{array}{l}\text { Dependable funding: but } \\
\begin{array}{l}\text { only for } \\
\text { activities derived from } \\
\text { standards requirements }\end{array}\end{array}$ & \multirow{3}{*}{ Programmes } & \multirow{3}{*}{ Cross-functional } \\
\hline & & 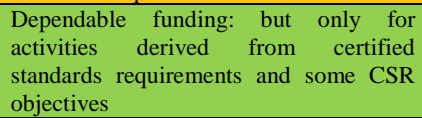 & & \\
\hline & & $\begin{array}{l}\text { Dependable funding: but only for } \\
\text { activities derived from certified } \\
\text { standards implemented. Employees } \\
\text { interviewed share the impression of } \\
\text { insufficient funding, which has no } \\
\text { correlation with the evidence found }\end{array}$ & & \\
\hline 6. Strategising/ & $\begin{array}{l}\text { Collaborative: Identification of } 6 \text { groups of stakeholders } \\
\text { and } 21 \text { subgroups; Collaboration and Transparency have } \\
\text { been defined as a core corporate value; Port Community } \\
\text { Association; Dirigentes Prize for the Best Business } \\
\text { Management; Impulso Prize for Excellence awarded by } \\
\text { the Local Government of the Principality of Asturias. } \\
\text { EFQM assessment showed that Society's APG perception } \\
\text { is not well known; there is no Employment climate } \\
\text { survey; there is room for improvement in diversity } \\
\text { management not based on gender; Quantitative } \\
\text { methodology to gather information from stakeholders }\end{array}$ & Substantial funding & $\begin{array}{l}\text { Systems: certified standards in key } \\
\text { CSR issues: environment, ISO } 14001 \text {, } \\
\text { and Health \& Safety, OHSAS } 18001 \\
\\
\text { Systems: certified standard in a key } \\
\text { CSR issue: environment, ISO } 14001 \text {. } \\
\text { Health \& Safety standard, OHSAS } \\
\text { 18001, implemented but not certified; } \\
\text { Employment climate survey }\end{array}$ & Organisational realignment \\
\hline 7. Transforming/ & Joint innovation & $\begin{array}{llll}\begin{array}{l}\text { Open-ended funding } \\
\text { commitment }\end{array} & \text { and resource }\end{array}$ & $\begin{array}{l}\text { Core integration - CSR as business as } \\
\text { usual }\end{array}$ & Institutionalisation \\
\hline
\end{tabular}

Note: The organisations have been represented in colours. Thus, Asturfeito is shown in orange, CTAI Ingeniería in blue, INMER in green and APG in red.

Source: Authors' own creation based on Maon et al. (2010) 